\title{
“... ora, isso faz muita diferença...” Tratamento da alteridade em \\ La beauté sur la terre, de \\ Charles-Ferdinand Ramuz
}

Vincent Verselle

Logo em suas linhas iniciais, o livro La Beauté sur la terre, de C.-F. Ramuz, publicado em 1927, apresenta-se como um romance sobre a alteridade: Juliette, personagem principal, é uma jovem cubana, filha de pai suíço e mãe espanhola. Órfã, viu-se levada, de súbito, a um vilarejo às margens do lago Genebra, ambiente que lhe era estranho, e para o qual ela não era menos estrangeira. E essa estranheza, antes até de a moça deixar sua terra natal, mostra-se problemática, o que as reflexões de seu tio Milliquet - proprietário de café, e que, a princípio, a hospedaria - manifestam indubitavelmente: “[...] mas sabe Deus como a criaram, e que hábitos terá adquirido, naquela região quente, naqueles lugares de pretos...”*.

Além da expressão, fruto de uma mente limitada, convém observar que, inicialmente, a estranheza se situa em uma alteridade cultural (educação e hábitos). Os outros personagens - os habitantes locais - adotam diversas posições com respeito à jovem cubana, as quais variam entre a rejeição definitiva, como a de sua tia ("É ainda pior do que eu pensei”*), que, aliás, acabará expulsando-a do café, e a esperança de uma aproximação quase familiar, alimentada pelo pescador Rouge, simbolizando a negação das distâncias geográfica e cultural: "Como no seu país? O seu país, agora, é este"**

"(Ramuz, Charles-Ferdinand.
"La Beauté sur la terre". "La Beauté sur la terre". sanne: Rencontre, 1953: 8.)

Mas, paulatinamente, a alteridade de Juliette se torna algo mais que uma diferença puramente cultural, passando a ser vista por várias personagens como uma diferença de nature$z a$ : ela não é apenas uma mulher jovem e bela, e atinge uma transcendência sobre-humana. "Eles não sabem quem é ela, não vêem a diferença"*, queixa-se o jovem Maurice Busset, que, tão logo notou esta diferença, abandonou sua noiva Emilie, tão simples, tão humana... Tal qual Afrodite, Juliette parece 
personificar a Beleza e resplandecer uma luz sobrenatural que atrai os homens para perto de si, como se fossem insetos.

$\mathrm{Na}$ esfera propriamente textual, não surpreende que o autor tenha aplicado um procedimento singularizante à figura de Juliette, a fim de ressaltar a sua alteridade. É esse aspecto que gostaríamos de abordar, em uma escala progressiva: primeiramente, destacaremos elementos assaz pontuais provenientes da composição descritiva do texto; em seguida, nós os relacionaremos com a estrutura característica do romance, considerando-os como efeitos desta; em suma, abordaremos a questão sob uma ótica genérica. Esperamos não encontrar entraves em nosso itinerário, o qual deveria nos conduzir às margens brumosas do fantástico, ainda que parta do sólido chão do realismo.

\section{Descrição: o sistema dos retratos}

\subsection{Visão global versus fragmentação}

A trama de La beauté sur la terre se passa no ambiente simples de um vilarejo às margens do lago Genebra, cenário perfeito para a ambientação de uma narrativa moldada em uma estética de caráter realista: nenhuma extravagância, nenhum acontecimento extraordinário naquele universo; ao contrário, há até uma certa monotonia reinando nele. Esse horizonte estético é, ao menos à primeira vista, sustentado pelas "pinturas de cenas cotidianas", multiplicadas pelo autor no romance, e presentes tanto no primeiro diálogo entre dois personagens bastante tipificados (o dono do café Milliquet e o pescador Rouge) quanto na festa da cidadezinha que encerra a narrativa e nas descrições do ambiente no café e das tardes de domingo passadas às margens do lago.

O sistema de retratos construído no interior do texto não raro se aproxima de uma estética realista; no primeiro capítulo, as descrições das duas personagens, apreendidas no meio de um diálogo, são paradigmáticas dessa aproximação. Eis o pescador Rouge:

Tinha um rosto grande e vermelho, usava um quepe de marinheiro com viseira de couro envernizado, e seu bigode era quase branco. Usava um agasalho de lã azul de gola alta que se abotoava na altura dos ombros. Baixo, gordo, corpulento, apoiava-se à frente de sua cadeira sem espaldar, batendo, de quando em vez, 
E, algumas linhas adiante: "Ajeitou o agasalho, que se ia dobrando em volta de seu corpo obeso, e, em seguida, o ergueu de um dos lados para apanhar um porta-níqueis [...]”*

Embora não exagere da profusão descritiva típica de um romance de Balzac ou Zola, o texto fornece indicações suficientes para termos uma imagem global da personagem ("baixo, gordo, corpulento”) e, ao mesmo tempo, características mais detalhadas que garantem o efeito de realidade do retrato (como o vestuário e os objetos), algumas das quais o texto, à medida que avança, repete, para lembrar ao leitor (o cachimbo e o bigode, mas também a corpulência, como já se pode ver neste capítulo). A lógica é, portanto, totalmente naturalista e muito zoliana. ${ }^{1}$

Seu interlocutor Milliquet tem direito a um tratamento semelhante, a despeito da lógica partitiva sob a qual constrói o retrato:

Enquanto gaguejava, Milliquet remexia o rosto enorme e flácido, um rosto cheio de dobras que partiam do queixo e subiam, como linhas de um caderno, por suas bochechas [...]. Levantou os ombros por baixo do colete de caça vermelho e de lã espessa, que abotoou de través por sobre uma camisa sem gola. Mantinha a carta em sua mão flácida de pêlos ruivos. [...] Moveu um pé, em sua sapatilha debruada, e, logo em seguida, o outro: o que fazer? oh, meu Deus, isso, o que fazer quando se tem um bigodinho descorado, e escassos pêlos descorados sobre suas bochechas grandes, flácidas e cobertas por sardas?"

Ainda que lhe seja impossível apreender por inteiro ${ }^{2}$ a personagem, o leitor nota que o tex to evidencia um número considerável de características, o que possibilita uma representação assaz concreta dela.

\footnotetext{
${ }^{1}$ Partimos das reflexões de Philippe Hamon (Le personnel du roman: le système des personnages dans les Rougon-Macquart d'Émile Zola. Genebra: Droz, 1983) sobre o "efeito personagem", bem como das de Jean-Louis Cabanès, que se inspira em Hamon: "A ilusão realista é produzida com a inscrição de signos reincidentes na memória do leitor. [...] Em L'Assommoir, Zola abandona a técnica do retrato balzaquiano, e Gervaise é descrita com pequenos retoques recorrentes em fundo de cenário variado" (Cabanès, Jean-Louis. "Naturalisme et écriture répétitive", Littératures, n. 29, 1993: 99)

${ }^{2}$ Um pouco mais adiante, entretanto, no capítulo IV, a descrição se completa: "De pé, ao lado da mesa, (grande, grave, suas calças que mal se prendiam, sua barba escassa, seu bigode amarelado) [...]." (BT: 41, grifos nossos.) Note-se, ainda, a retomada de detalhes específicos (a barba, o bigode).
} 
Desse modo, conforme um pacto de leitura de um romance tipicamente realista, as personagens, desde a sua primeira aparição, são apreendidas como um todo e descritas em suas especificidades. Somente Juliette, protagonista, escapa a tal procedimento. Quando, no segundo capítulo, sua entrada em cena poderia ser o momento providencial (quase obrigatório, diríamos) para a feitura de seu retrato, nossa expectativa leitora não é respondida, de fato, e essa decepção é, no mínimo, comparável à dos personagens, à de Milliquet principalmente:

[...] No cais, nada mais sobrou à sua frente, a não ser uma coisinha mísera e cinzenta. Alguém sem pés, nem braços, encolhido dentro de um casaco de chuva com capuz; Milliquet não lhe viu nem mesmo o rosto.*

De imediato, Juliette apresenta-se como uma ausência de determinações, sem cores, sem rosto, a tal ponto que o texto parece até despersonalizá-la: note-se que o substantivo que primeiramente a designa é "coisinha", reformulado, em seguida, como "alguém".

Esse anti-retrato inicial é programático; não teremos oportunidades reais de substituir a lacuna "coisinha cinzenta” por uma representação global mais precisa: não há sequer outro retrato de Juliette em todo o romance. ${ }^{3}$ Ao contrário, assim como Juliette aparece aqui totalmente disforme, privada de partes (pés, braços, rosto), as figuras subseqüentes dela montadas serão sempre da ordem do fragmento. Poderíamos somar os exemplos em que se trata unicamente de um braço, de um ombro, de uma perna ou do sorriso de Juliette, que nos é permitido ver. Com menor recorrência, esses elementos estão presentes na mesma seqüência, mas não são, de fato, reunidos. Limitar-nos-emos a citar um excerto, que, a nosso ver, revela de modo luminoso (medindo-se o qualificativo) o sistema descritivo que opõe Juliette a todas as outras personagens de La beauté sur la terre. De madrugada, três personagens estão em um barco - Juliette, o pescador Rouge e Décosterd, seu ajudante:

${ }^{3}$ A noção de "programa" não está empregada sem rigor; a restituição da primeira aparição de Juliette anuncia, incontestavelmente, a de seu desaparecimento final, do mesmo modo: "Ela ainda ergue os braços; em seguida, está sem braços, sem corpo; imediatamente, não está mais [...]” (: 256, grifos nossos). 
Décosterd pegou a lanterna, levantando-a, depois. Uma chama fosca atravessava o vidro convexo, colorindo insatisfatoriamente a palidez do horizonte. Em seguida, os dois homens foram iluminados em toda a frente de seus corpos, da cabeça aos pés, também no bigode, e nos coletes. Passaram a lanterna à Juliette, ela o deixava ao lado, no compartimento de trás. Também ela foi iluminada, mas apenas de um lado do corpo, no ombro, no braço, na perna esquerda; enquanto isso, mantinha as pernas levantadas, abraçando os próprios joelhos, para não dificultar a manobra. Ela era uma de suas bochechas, uma de suaspernas, um de seus pés descalços. [...]

O sol a ama tanto quanto a nós, seus velhos freqüentadores e companheiros de todo dia. Ele incide em uma bochecha, uma têmpora, uma parte dos cabelos, cujas madeixas retas brilham como lâminas de aço. $O$ pontilhado de sua pele se mostra no pescoço, em um lado seu, e, na frente, bem no começo.*

Segundo as indicações do texto, a luz parece apreender os homens em sua totalidade ("da cabeça aos pés"), enquanto de Juliette só sugere captar alguns fragmentos. A textualidade desses elementos enfatiza seu caráter esparso. De fato, se retornarmos aos retratos de Rouge e Milliquet, anteriormente citados, constataremos que as partes extraídas das personagens permanecem como as partes de um todo organizado, porque esses retratos preferem uma sintaxe preposicional (de, sobre, sob, em etc.), que situa as partes umas com relação às outras. Por outro lado, no excerto acima, os membros de Juliette se inserem em uma estrutura sintática acumulativa, uma enumeração em que as preposições, se as houver, não desempenham a função de organizar os elementos entre si. E se a organização destes parece acontecer no fim da seqüência, é para nos fazer ver então partículas da personagem. Certamente, esta seqüência é mais rica em elementos que o anti-retrato inicial; dela entretanto não resulta nenhuma representação global de Juliette. Ao contrário, sua figura é "dividida” em pedaços cada vez menores, até restringir nosso campo de visão ao pontilhado da pele da moça!

\subsection{Especificações versus partes}

Contestar-se-á que essa seqüência - quiçá outras - exemplifica, de qualquer modo, uma tentativa de elaboração de um "retrato" da personagem, ou que é, ao menos, uma operação com função representativa. É verdade que a fragmentação de Juliette pode figurar como uma primeira operação de 
aspectualização - a decomposição em partes do objeto que se quer descrever. Mas isso significaria para o leitor um ganho efetivo em termos cognoscíveis? Caso se tratasse de uma criatura desconhecida, a aspectualização seria, de fato, a primeira etapa de um retrato. Além disso, quanto a Juliette, o fato de assegurar-se de que ela possui cabelos, um rosto, dois braços, duas mãos, ombros, pernas e pés tem mesmo alguma utilidade para que o leitor possa imaginá-la concretamente? Todas essas informações já estão contidas no conceito "mulher", que o leitor não pode ignorar. Se a figura de Juliette se distingue de todas as outras, não é somente porque é fragmentada, mas sobretudo porque não é caracterizada pelo mesmo código, que identificamos anteriormente como realista. Os aspectos (braços, pernas etc.) depreendidos do tema-título, "Juliette" - para empregarmos os termos das teorias da descrição -, quase não são, por sua vez, tematizados; logo, não se tornam suporte de uma nova operação de aspectualização, que, por exemplo, decomporia uma perna em cor, largura, espessura etc. ${ }^{4}$ Muitas vezes, apenas um aspecto é depreendido, e a qualificação remete à noção abstrata de "beleza": "desamarrou o xale sobre seus belos braços", "levantava a cabeça abaixo de seus belos cabelos", "com seus belos pés descalços, pisava sobre os calhaus", "seus belos ombros brilham sob o sol", "ela se move na direção dele com suas lindas pernas" etc."

Ao fim do romance, enfim, descobrimos que Juliette é uma mulher, que é bela, e até algo mais, já que tivemos acesso a alguns qualificativos um pouco mais concretos (seus cabelos são negros, suas canelas, finas, seu pescoço, redondo - que descoberta! - etc.). Mas esses elementos se encontram dispersos no conjunto do texto. O quadro reproduzido em anexo (A1) é a soma, reorganizada aos nossos cuidados, dos elementos de retrato que podem ser garimpados ao longo dos 13 capítulos do romance. Ele permite constatar, facilmente, no que concerne à descrição do corpo de Juliette, a desproporção entre um primeiro nível de aspectualização, que nos dá aces-

${ }^{4}$ Extenuado por essa terminologia, o leitor poderá recorrer a Yves Reuter (La Description. Des théories à l'enseignement-apprentissage. Paris: ESF, 2000), que emprega, possivelmente, uma mais compreensível - de que nos utilizamos para nosso subtítulo -, distinguindo o todo (objeto exposto em sua totalidade), as partes (aquilo que compõe o objeto, por exemplo, os membros) e as especificações (que caracterizam ou o todo ou as partes, como uma cor ou um talhe). 
so às diferentes partes que compõem a moça, e um segundo nível, que fornece apenas algumas especificações dessas partes. Por outro lado, nesse tocante, conhecemos melhor Milliquet ou Rouge, e isso após a leitura de um único capítulo (cf. anexo A2).

Caso se tratasse de um romance dos séculos XVII ou XVIII, a heroína poderia estar na condição de "casa vazia" sem que isso parecesse problemático. Como lembra Philip Stewart, nos romances do século XVIII,

$\mathrm{o}$ atrativo da mulher não depende de suas qualidades próprias e únicas. Fala-se sempre de sua admirável brancura [...]; seu busto sempre é 'perfeito' ou 'o mais belo', bem como seus outros 'tesouros'. Não é nunca a claridade vivaz de seus olhos verdes ou azuis, a ponta de seu nariz empinado, ou até o balançar de sua ancas: nada de formas precisas, tudo é reduzido a um denominador comum, que é o desejo inspirado por ela. ${ }^{*}$

Em um quadro estético como este, a apagada figura de Juliette não destoaria mesmo. Mas, como dissemos no início do artigo, o sistema dos retratos de La beauté sur la terre se fundamenta em uma estética realista. Nesse sentido, o procedimento descritivo adotado para Juliette é, portanto, diferencial. Ele, todavia, não torna impossível toda e qualquer ilusão referencial; Juliette possui uma “existência”, ela é mesmo um (efeito) personagem. Parece-nos que isso é resultado de dois componentes textuais. Primeiramente, o princípio de recorrência, que J.-L. Cabanès considera como o núcleo do efeito-personagem perseguido por uma escrita realista-naturalista, vale para todos os personagens de La beauté sur la terre, inclusive para Juliette. Desse modo, como dissemos, a qualificação belo(a) é muitas vezes recorrente, como também o são a cabeleira e o vestido pretos da moça, ou o cachimbo e o bigode branco de Rouge.

A outra fonte de ilusão referencial é mais difusa e menos destacável por índices textuais claros. Ela se encontra, já no primeiro capítulo (quando Juliette ainda não possui realidade alguma, e nem mesmo seu nome se conhece), na convocação do estereótipo da bela latino-americana. É assim que entendemos a pergunta que Rouge faz a Milliquet, de maneira quase inoportuna: "O cônsul não te diz se ela é bonita?"*

Fica claro que Rouge se fundamentará, imediatamente, em um imaginário estereotípico, e a agitação provocada pela chegada de Juliette (no café, todos se empurram querendo
"(Stewart, Philip. LeMasque et la parole. Le langage de l'amour au XVIII' siècle. Pa ris: Corti, 1973: 47.)
" (Ramuz, C.F. La beauté sur la terre. Ob. cit.: 10.) 
(Dunoyer, Jean-Marie. "La Beauté sur la terre. Roman de C.-F. Ramuz", La Vie alpine, janvier 1929: 8.) vê-la) sustenta essa referência, que nós, leitores, acionamos indiretamente no intuito de conferir uma certa aparência ao personagem não-descrito. Ademais, os poucos elementos representacionais fornecidos pelo texto nunca vão de encontro ao estereótipo, mas, ao contrário, corroboram-no (cor dos cabelos, tom amarronzado da pele). Até aqui há um tipo de "redundância" que favorece a criação de um efeito-personagem mínimo, ao menos o suficiente para que nossa leitura não seja impedida. Mas o fato de um estereótipo ser explicitamente convocado como substituto a uma descrição de Juliette evidencia ainda mais a manutenção do personagem, mediante um procedimento diferencial, em um estado de frágil representação.

\section{De um quebra-cabeça a outro: narração e "focalização"}

Influenciada pelo título La beauté sur la terre, a crítica se limitou à análise de um conteúdo do romance em particular, isto é, regalou-se com algumas reflexões metafísicas que perpassam por várias passagens do texto, em particular, por aquelas em que a harmonia do mundo seria devolvida por Juliette, com sua presença frágil e passageira - porque a beleza, como se sabe, é efêmera...

Compreendida sob essa ótica, a lacuna representacional que mostramos se interpreta facilmente: "Nada há de tão belo, para nós, além dessa Beleza que não se vê"* .

Para que um personagem possa representar o sumo da beleza, o seu absoluto, ele não deve ser muito encarnado, muito humano; isso parece compreensível, e o apagamento de Juliette teria, por fim, uma necessidade temática evidente.

A crítica, no entanto, chegou a essa constatação negligenciando a estrutura do romance. Há aí uma lacuna que nos propomos a preencher: primeiramente, porque o apagamento de Juliette é um efeito da estrutura característica do texto - eis um tipo de evidência que convém repetir algumas vezes -, daí não ser possível interpretar o valor de tal apagamento fora de uma análise estrutural; e, em segundo lugar, porque essa análise levará a privilegiar precisamente uma leitura plural do romance, em lugar de uma interpretação unívoca.

Se o sistema dos retratos de La beauté sur la terre resulta de uma estética realista, ao mesmo tempo dela se distancia 
consideravelmente. Como o leitor se dá conta rapidamente, a narração é extremamente partida, pelo viés de incessantes delegações de condução da narrativa; e, do mesmo modo, o regime de focalização é instável, preferindo-se a multiplicação dos pontos de vista a uma gestão mais homogênea. Ao inverso do que habitualmente ocorre em uma narrativa de matriz realista - com narrador de preferência onisciente -, nenhuma instância deste tipo emerge no romance de Ramuz. Nenhuma voz, nenhum olhar controlam o conjunto do universo fictício constituído pouco a pouco pelo texto, o que tem por conseqüência tornar impossível a fixação da representação de Juliette, a um só tempo personagem e objeto principal do texto.

\subsection{Delegação e polifonia}

Precisemos a forma que o agenciamento narrativo do texto toma. A presença de um narrador primeiro é indubitável, pois é sensível em algumas passagens; ele se permite, por exemplo, acelerar a narrativa por meio de elipses ("Vários dias se passam [...]”); assinala, com comentários, sua posição elevada relativamente às personagens, como no seguinte, quando Décosterd descreve a virtuosidade do acordeonista corcunda: "Não há o que dizer: ele tinha brilho (Décosterd era conhecedor)"**. Fornece, enfim, em particular nas seqüências descritivas, algumas informações gerais sobre a ambientação da trama; desse modo, o incipit do capítulo V abunda em indicações dessa natureza:

É aqui, às margens do lago, em uma região muito plana (e regiões planas são raras por aqui) [...].

Entre a linha do trem e a água, há uma estranha mistura de lugares desérticos e cultivados (coisa rara por essas paragens); a paisagem é ora campesina, ora vinícola, e os grandes trens são poucos, como dissemos, não há muitas fazendas importantes, tampouco casas notáveis, já que por aqui elas são menores que no resto do país. [...] Daí chegava-se até Bourdonnette. E lá tínhamos água à nossa frente, ao passo que sempre a tínhamos ao lado; mas apenas uma pequena largura d'água, ladeada, na outra margem, por uma falésia bastante escarpada. [...]

Era preciso tirar os sapatos caso quiséssemos subir a falésia e em seu cimo, de onde se tem uma bela vista [...] No alto, estão os Grandes Bosques, assim os chamamos, embora nem tão grandes sejam, mas bem densos, e, do lado de Bourdonnette, particularmente íngre-

" (Ramuz, C.F. La beauté sur la terre. Ob. cit.: 21 .)

"(: 170, grifo nosso.) 
"(: 47.9, grifos nossos.)

"(: 14, grifo nosso.)

"(Genette, Gérard. Figures III. Paris: Seuil, 1972: 253, nota 1.) mes e acidentados, enquanto, do lado do lago, projetam-se para o nada; aos domingos, enchem-se de casais apaixonados e passeadores."*

Mas, a natureza dessa instância narrativa primeira - sua "localização" diegética, diríamos - é problemática, o que o trecho acima deixa claro. A postura comentadora do narrador primeiro e o saber que ele detém sobre as personagens poderiam situá-lo "fora" da diegese, mas uma seqüência descritiva como essa, por sua própria estrutura (a descrição é feita "em movimento" e o próprio narrador parece fazer o percurso) e, principalmente, pela presença de pronomes associados à primeira pessoa do plural ou do pronome indeterminador do sujeito, faz surgir uma hesitação: o narrador primeiro seria heterodiegético ou homodiegético? Evidentemente, a instância narrativa primeira não é uma das personagens, pois as informações gerais que mencionamos não podem ser atribuídas, definitivamente, a nenhuma delas. Todavia o narrador "aparece" algumas vezes na diegese, furtivamente e em segundo plano, como no capítulo II, em que Rouge e Milliquet seguem, em um atlas geográfico, o trajeto feito por Juliette de Cuba às margens do lago Genebra: " $\mathrm{E}$ ali, enfim, o oceano escancarava-se à nossa frente, enquanto Rouge tentava imaginálo $[\ldots]$...*.

Nesse caso (e em alguns outros), o estatuto homodiegético do narrador é incontestável: ele se inclui no mundo narrado, como um membro anônimo da comunidade que constitui a trama. Ora, esse anonimato é uma característica a ser sublinhada; Genette, ao distinguir dois tipos de narradores homodiegéticos, menciona, ao lado dos narradores heróis de suas próprias histórias, aqueles que desempenham apenas um papel de observador. Em nota, acrescenta: "Uma variante, nesse tipo, é a narrativa cujo narrador é testemunha coletiva: a tripulação de Nègre du Narcisse, composta pelos habitantes da cidadezinha de $A$ rose for Emily. Lembre-se que as primeiras páginas de Bovary são escritas nesse modelo"*. Essa noção parece convir perfeitamente à natureza do narrador primeiro de La beauté sur la terre: indefinido, plural, difuso, parecendo conhecer a trama e as personagens como se tivesse vivido a história, embora não seja um de seus protagonistas. Ela permite igualmente expor a situação de equilíbrio que seria a do narrador primeiro, simulta- 
neamente "fora" e "dentro" da diegese, assim como uma testemunha se encontra no espaço em que ocorre um acontecimento, sem, no entanto, participar efetivamente dele. ${ }^{5}$ Enfim, o estatuto de narrador testemunha coletiva é, no nosso ponto de vista, uma chave para a compreensão do romance: simples observador, esse tipo de narrador se encontra em uma posição hierárquica quase idêntica à das personagens no que concerne ao saber e à interpretação dos fatos. É uma testemunha entre outras (o que tem conseqüências quando se trata de determinar o "sentido" de um texto), e veremos que o texto tende a provocar esse nivelamento hierárquico, tanto em seu componente narrativo quanto em seus aspectos estritamente gramaticais.

Afirmamos anteriormente que o narrador primeiro delega freqüentemente a condução da narrativa. Esse simples fato pode ser visto como um artifício realista: há um ganho de "objetividade", permitindo-se que se exprimam os protagonistas da história. Paralelamente, isso também deve ser entendido como um elemento de encenação da "fraqueza" do narrador primeiro, que, remanejado à categoria dos narradores segundos, se vê como que forçado a "Ihes passar o testemunho". Isso se opera explicitamente com uma marcação tipográfica - o emprego de aspas - por três vezes. O pescador Rouge narra, em parte, a primeira aparição pública de Juliette $^{*}$ e, mais adiante, as circunstâncias em que recebeu a moça em sua casa, após ter sido expulsa por sua tia*. Do mesmo modo, os acontecimentos que encerram a narrativa são parcialmente narrados por uma instância indefinida ${ }^{6}$, representante da voz dos moradores do vilarejo* ${ }^{*}$ O enunciado que organiza a primeira transição-delegação explícita torna claras as relações hierárquicas entre os narradores: "Agora é Rouge quem toma a palavra"*.

Parece-nos instigante que Genette trate desse tipo de narrador em apenas uma simples nota, como se dele quisesse se desembaraçar. O narrador, testemunha coletiva, por natureza, torna de fato relativo o abismo que Genette tenta cavar entre os modos heterodiegético e homodiegético, tamanha a sua rigidez quanto a essa fronteira. Ao nosso ver, a narratologia, fazendo mais caso desse "parente pobre", com ele poderia ser revigorada mais do que enfraquecida.

${ }^{6}$ Ela se exprime indiscriminadamente por meio de "nós" e de marcas de indeterminação do sujeito. Note-se que dois "eu" aparecem furtivamente em uma frase (BT: 251), sem, no entanto, fazer com que a instância narrativa perca seu anonimato.
"(Ramuz, C.F. La beauté sur
la terre. Ob. cit.: 27.9 e 31-2.)
"(: $85 \cdot 7$.

(:222-3e 250-2.)

"(:27.) 
(Bakhtin, Mikhail. Le Marxisme et la philosophie du langage. Paris : Minuit, 1977.)

"(Ramuz, C.F. La beauté sur la terre. Ob. cit.: $128 \cdot 30$, grifos nossos.)

"(: 131, grifos nossos.)
A própria expressão da mudança de narrador não é a de uma delegação benevolens, inteiramente agenciada pelo narrador primeiro; o que o texto diz é que aquele parece não poder proceder de outro modo, a não ser permitindo que Rouge narre, igualmente, uma cena de La beauté sur la terre. Embora a posição dominadora do narrador primeiro se propague, de modo particular nos comentários que destila sobre as personagens, ela não lhe permite afirmar uma "autoridade”, o que acarreta, desconfiamos, conseqüências importantes à interpretação do texto.

A flutuação da hierarquia narrativa é provavelmente ainda mais decisiva nos casos em que a delegação da narração está "não-declarada", pelo viés quer do discurso livre, quer do discurso indireto livre. $\mathrm{O}$ emprego desta modalidade de discurso reportado, e seus efeitos em matéria de polifonia são conhecidos; eles foram brilhantemente demarcados por Mikhail Bakhtin*, a cuja teoria remetemos o leitor, preferindo nos aplicarmos ao emprego do discurso direto livre, menos comum. Assim, a cena de pesca que reúne Juliette, Rouge e Décosterd, já parcialmente mencionada, é predominantemente narrada segundo essa modalidade de discurso reportado. O espaço de uma linha separa o excerto que já citamos da seqüência a seguir:

Ela continuava a pescar conosco. Continuava tendo seu lugar entre nós, quando subia no barco a cada manhã e ia conosco retirar as redes. [...] Com o bom tempo que fez todo este fim de mês e uma grande parte do mês seguinte, eles se põem a caminho, os três, e a parte do mundo onde ela está é a nossa. [...] Ela sentiu-se completamente em casa aqui, talvez por algum tempo, porque não havia ninguém, isto é, éramos apenas ela e nós; ela e nós, e as coisas e nós. [...] Ela ainda puxava um pouco a corda da esquerda, e ia-se contra a baliza. Rouge e Décosterd abandonavam seus remos, e Décosterd corria à frente [.....*

De modo semelhante, no fim da passagem: "Ah! ela estava mesmo em seu lugar! O sol, quando apareceu, não fez distinção alguma entre ela e eles. $\mathrm{O}$ sol a ama tanto quanto a nós, seus velhos freqüentadores, seus companheiros de todo dia"*.

O espaço em branco que destaca essa seqüência da precedente poderia ser interpretado como uma vontade de assinalar a mudança da instância narrativa e distinguir a voz do narrador primeiro daquela do(s) narrador(es) segundo(s). A continuação do texto, porém, desestabiliza esse primeiro 
movimento suposto, e, ao contrário, é a coexistência que se instala: note-se que o "nós" sinaliza que a narração é o fato de Rouge e Décosterd concorrerem com designações (os nomes próprios, o pronome "eles" etc.) que indicam uma incumbência "externa". Nessa seqüência, como em muitas outras, o vai-e-vem entre as duas modalidades de incumbência narrativa é tão estreito que as vozes acabam se sobrepondo, como se lutassem entre si. Prova disso é a frase "Com o bom tempo que fez [...] é a nossa”, em que é simplesmente impossível determinar "quem” está referido pelo pronome pessoal "nossa"; ou, também, o fato de o enunciado: "O sol, quando apareceu, não fez distinção alguma entre ela e eles” ser, logo em seguida, reformulado em uma modalidade homodiegética. Tais fenômenos provocam efeitos polifônicos tão importantes quanto o emprego do discurso indireto livre. Ou melhor, o "jogo" que o discurso direto livre cria entre as diferentes vozes (com a alternância breve entre pronomes de primeira e terceira pessoas) permite manifestar a tensão existente entre os fios desse entrelaçamento narrativo.

Em um sistema tão complexo, o pronome índice de indeterminação do sujeito, bem como os pronomes associados à primeira pessoa do plural desempenham, logo, papel preponderante. Por remeterem tanto ao narrador primeiro quanto aos narradores segundos, transformam-se em passarelas enunciativas, permitindo rápidas transições de uma voz a outra. Esse aspecto gramatical, como dizíamos, mostra o funcionamento essencial do texto em seu aspecto narrativo: tudo nele tende a aproximar as diferentes instâncias narrativas.

\subsection{Focalização, ocularização, auricularização}

Com a perda da hierarquização das vozes narrativas, somos obrigados a constatar uma outra "falta", tão substanciosa quanto ela: a de um efeito de controle do mundo narrado. Quando um texto constrói a imagem de um narrador heterodiegético onisciente, ou até de um narrador homodiegético que, no instante dos fatos, nada sabia, mas, no momento da narração, pode aspirar àquele conhecimento, isso se traduz (para o leitor) como uma forma de segurança interpretativa. Mesmo quando o texto põe em cena várias vozes, várias instâncias narrativas às vezes dissonantes, há uma delas que confirma seu domínio sobre o mundo narrado e impõe "verdades" que, 
sozinhas, podem ser entendidas como tais. Em La beauté sur la terre, a voz do narrador primeiro não possui a mesma solidez interpretativa; nesse aspecto, ela é posta no nível das outras vozes narrativas que se fazem ouvir ao longo da narrativa. Nenhuma fala entrega ao leitor uma chave que permite a apreensão do mundo narrado em sua totalidade; cada narrador não faz senão exprimir um fragmento dele, uma porção que se limita ao que ele pode saber.

Um fenômeno restritivo parecido entra em jogo no plano da percepção-restituição do mundo narrado; desse modo, o acesso ao mundo ficcional é viabilizado por meio de pontos de visão e, às vezes, pontos de escuta. Com isso, ninguém se surpreenderá: se o(s) saber(es) exposto(s) no texto é (são) limitado(s), parece bem natural que o mesmo aconteça no campo perceptivo.

Tomemos como exemplo a seqüência descritiva "em movimento" do incipit do capítulo V; o trajeto que percorremos conduz ao alto da falésia que sobranceia o lago. Pois bem, é desse ponto preciso que o texto convida, primeiramente, a ver os acontecimentos relatados no começo do capítulo: "Era do alto da falésia, no começo de junho [...]. Os dois homens [Rouge e Décosterd] formavam duas manchas negras, e continuavam formando duas manchas negras, vistos do alto, aplanados; formavam duas manchas ovais na pedra cinza (de perto rosa, azul-claro, violeta, branca)"**.

A continuação da cena - um diálogo entre os dois homens - é construída em uma perspectiva, a de Décosterd, o que se torna claro com a presença em cena de um processo interpretativo posto em xeque, e o leitor compreende, pouco a pouco, que a ajuda de Rouge é a fonte dele:

De braços cruzados, Rouge analisava sua obra.

[...] Mostra as tábuas do depósito [...]; mostra a parede de tijolos com fendas aqui e ali - e o mais estranho é que ao mesmo tempo ele parecia satisfeito [...].

O lugar estava a ponto de ir abaixo... E nem mesmo reparavam naquilo, é que eles mesmos estavam indo abaixo...

Ele dizia isso no passado (por que no passado?); e continua:

"E você, Décosterd, o que acha disso?"

Décosterd responde gesticulando com a cabeça. Ele falava pouco. Mostrava ter a mesma opinião [...]; surpreendia-lhe, portanto, ver 
a expressão que tinha o patrão diante da velha construção e do hangar em tão más condições [...].**

"(: 50-1, grifos nossos.)

Toda a cena é construída assim, e seu pivô é uma mudança de focalização: antes, externa, e após, interna, a respeito de Décosterd. Logo, não há focalização zero; nos dois casos, trata-se, como dizíamos, de um acesso restrito ao mundo ficcional.

O termo "focalização" não parece, entretanto, dar conta das nuanças dessa estrutura, pois tende a mesclar o modo de percepção do mundo e o conhecimento que dele é transmitido. Assim, uma dissociação entre o ver e o saber terá sido percebida no início da cena (em "focalização" externa); as personagens e o cenário são mostrados de um ponto de vista distante, mas o narrador não demora a preencher uma lacuna do saber, desestabilizando aquilo em que essa percepção leva a crer (no tocante à cor das pedras do lago). A organização dos aspectos perceptivo e cognitivo parece ser feita, então, de dois modos singulares, daí ser importante, ao nosso ver, não os confundir dentro de uma única noção - ainda que, façamos uma concessão, os dois aspectos se entrecortem em vários pontos. Preferiremos falar de ocularização, abarcando pontos de visão, e de auricularização ${ }^{7}$, para os pontos de escuta, de que temos um exemplo perfeito no capítulo IV; Rouge comparece no café mantido pelo tio de Juliette, Milliquet, que hospeda a moça: "Ao abrir a porta do bar, ele [Rouge] se surpreendeu em ver que o lugar estava vazio. Espera um momento; ninguém chega. Esperou; em seguida, escutou-se o barulho de uma discussão vindo da cozinha, e, pelas paredes, reconhece a voz de Milliquet; reconhece, depois, a voz da servente. Ninguém aparecia, ele teve de chamar."*

Milliquet aparece logo após, e uma discussão entre as duas personagens tem início. Depois, escuta-se, ao longe, uma música; note-se que a menção a esse acontecimento é feita segundo

\footnotetext{
${ }^{7}$ Essas categorias são elaboradas por François Jost em L'CEil-caméra (Lyon: Presses Universitaires de Lyon, 1987), que aperfeiçoa vários pontos da narratologia de Genette. Tal escolha se nos impôs ao lermos a dissertação de Rudolf Mahrer (entregue na Universidade de Lausanne), que aborda um outro romance de Ramuz, Les Signes parmi nous. Uma síntese do estudo de Mahrer pode ser encontrada em um de seus artigos: "Poétique ramuzienne du tableau: Les Signes parmi nous (1919)", Etudes de lettres (revista da Faculdade de Letras da Universidade de Lausanne), n. 12, 2003: 265-96.
} 
de um ponto de percepção: “[...] lá, por detrás do boliche, sob o céu que clareava sem parar, mas, aqui, estamos sob as lâmpadas, não demorou, e o acordeão começou a tocar."*

A dissociação entre perceber e saber notada anteriormente se manifesta uma vez mais: enquanto os dêiticos ("lá" versus "aqui”) circunscrevem o ponto de escuta do qual a música é percebida ${ }^{8}$, as informações espaciais e meteorológicas ("por detrás do boliche", "sob um céu que clareava") fornecidas como complemento só poderiam vir de uma outra fonte (o narrador primeiro) - o que certamente é ressaltado pelo "mas" que articula o enunciado e delimita dois campos, o da percepção e o do conhecimento do mundo. Em outras palavras, a cena é bem organizada "sensorialmente", em torno de um ponto específico do espaço: dois homens no salão de um café; não se trata, portanto, de uma restrição de focalização do tipo interna: o leitor "sabe" mais a respeito do que as personagens; por exemplo, que o céu "clareia" muito mais "lá".

Não resistimos ao prazer de citar a continuação da cena, pois o acordeão também foi percebido por uma outra personagem, Juliette, recolhida em seu quarto, mas que procurava, discretamente, ir embora da casa. Dessa maneira, o texto faz com que se alternem dois planos, um voltado principalmente para aquilo que a moça ouve ${ }^{9}$, e outro que é a continuação do diálogo entre Rouge e Milliquet, até que o todo coexista em um plano apenas, no momento em que Juliette está no corredor, a um passo de sair:

[...] o ar de dança que lhe circunda o corpo ganhou até mesmo o corredor, quando ela abriu a porta da casa...

"Deixe-a livre", diziam no bar. O que você quer é que ela trabalhe? Ela não foi feita para isso. Deixe-a livre, senão você pode apagá-la...

Por um instante, o instrumento veio girar ao redor dos dois homens, e roda um pouco debaixo dos abajures de cúpula esmaltada:

"É como as asas das borboletas: se você as toca, elas se tornam cinzas... Deixe-a correr... Quando não souber mais o que fazer com ela, é só mandá-la para mim."

${ }^{8}$ Notem ainda a formulação "e o acordeão começou a tocar": escuta-se o som do instrumento, e não que alguém o está tocando.

9 "Ela foi até a porta. Escuta, com a orelha colada ao fino painel de pinheiro. Não se ouvia outro barulho na casa, a não ser um surdo rumor vindo do andar térreo [ a conversa entre Rouge e Milliquet $]$ [...]”" (Ramuz, C.-F. La beauté sur la terre Ob. cit.: 42). "[...] ela entrou para o patamar. Ninguém no patamar, menos ainda na escada" (: 43). 
Mas a porta da casa se fechou novamente. E ela, agora, está do outro lado da porta, is to é, do lado certo.*

Não escutamos uma palavra a mais da conversa. Aqui, novamente, um "mas", rispidamente, lembra onde se situa o centro da percepção: Juliette está no outro lado, fora da casa. As duas últimas réplicas foram "registradas" porque ali estava ela para as escutar - sem saber, entretanto, quem estava falando, o que é expresso pelo sujeito indeterminado de "diziam" substituindo uma designação mais esperada ("Rouge"). $\mathrm{E}$, simultaneamente, a presença de alguns elementos que não se enquadram neste universo perceptivo ("dois homens", "os abajures de cúpula esmaltada”) indica que não se trata, contudo, de um regime de focalização interna que controla o acesso cognitivo ao mundo narrado; há sempre uma dissociação entre os dois planos.

No decorrer deste trabalho, não faltará oportunidade de voltar a essa questão da percepção. A exploração de alguns exemplos tinha como objetivo levar à seguinte constatação: a restituição do mundo ficcional - quer no plano narrativo, quer no plano perceptivo - sempre está submetida à ordem do fragmentário. Nenhuma fala pode pretender ultrapassar as outras em veracidade, todas elas só contam com a fiabilidade relativa de um testemunho concernente a uma porção apenas do mundo narrado, ainda que nesse concerto a voz do narrador se destaque um pouco por meio de um ganho informativo substancial. Do mesmo modo, nenhuma instância, o narrador primeiro ou as personagens, pretende apreender sensorialmente o mundo em sua totalidade. O "real" não é oferecido ao leitor de bandeja, aberto sobre uma mesa como um mapa geográfico; ele permanece tridimensional e conserva, assim, suas perspectivas e, logo, suas faces ocultas.

Em tais condições, parece evidente que Juliette conserve sua opacidade inicial, tanto mais por ser um elemento totalmente estrangeiro ao universo em que surge; como expressa seu tio Milliquet antes de sua vinda, não se dispõe de nenhum conhecimento sobre ela: "Eu não sei nada, nada, nada...”*. Qualquer informação relativa à personagem depende, então, dos núcleos perceptivos disponibilizados pelo texto; parece ser isso, pois, a causa principal da fragmentação dessa figura: ela é pega em um lampejo de olhares, os mesmos que, em grande parte, desmembram-na. Lembre-se que 
é um "nós" (representando a voz de Rouge ou a de Décosterd) que, prioritariamente, conta a cena de pesca no despertar do dia, e cujo olhar detalha o corpo da moça em partes cada vez menores; a seguir, mais duas ocorrências, entre outras, desse dispositivo: "Ele [Rouge] olha para ela, é tudo o que pode fazer. Olhava seus cabelos; ela tinha lâminas de punhal nos cabelos, de tanto que brilhavam. Ele olhava seu pescoço, seus olhos, suas bochechas; o que nunca acabava, pois havia ainda a boca, a testa..."* "Encostada na parede, ela esperava. Ela sempre sorri com aqueles dentes reluzentes. Ele [Rouge] não ousa olhar para eles".*

Inegavelmente, o texto restitui o percurso saltitante do olhar, o vai-e-vem das pupilas que coletam migalhas de real. A lógica da percepção é respeitada; em contrapartida, nenhuma instância superior vem reorganizar as partes em um todo "coerente", o que significa que nenhum conhecimento se extrai dessas percepções, de modo "sintético", para usarmos a terminologia kantiana. Apenas as percepções "analíticas", sempre as mesmas, são repetidas, e o fluxo representacional persiste até o término do romance. ${ }^{10}$

\section{A tensão fantástica}

Se as percepções não levam a um conhecimento da personagem, o fluxo ganha, então, a dimensão interpretativa do texto. Nesta última seção, gostaríamos de destacar, primeiramente, dois grupos de elementos que acabam de mostrar em que sentido La beauté sur la terre é um romance cujo tratamento narrativo não busca construir uma legibilidade maximizada do mundo, e que é, assim, em grande parte, "não realista”. Isso levaria, então, a apreender o conjunto do texto em uma nova perspectiva genérica.

\subsection{Topoi renovados}

Quantas narrativas não se passam em uma noite sem luar, ou mesmo em um imenso nevoeiro? Quantos narradores não

${ }^{10}$ Afirmar "um triângulo possui três lados" é estabelecer um julgamento analítico, pois o conceito "triângulo" inclui a noção "três lados". Dizer "este triângulo é bonito" é realizar um julgamento sintético e atribuir ao sujeito do enunciado uma qualidade que, conceitualmente, ele não possui. Vê-se de que modo a síntese permite singularizar, concretizar um objeto do mundo, ao passo que a análise se confina na esfera da abstração. É propriamente o que acontece em nosso romance com a figura de Juliette. 
confessam estar tomados pelo cansaço ou sob o poder de alguma substância psicotrópica? Esses elementos aparecem como topoi do gênero fantástico; não são fenômenos estruturais, mas componentes diegéticos. Sua função é problematizar a percepção do acontecimento motor da trama e, assim, tornar possível uma tensão interpretativa como encerramento da narrativa.

Em La beauté sur la terre, a primeira aparição de Juliette é decepcionante em termos de representação: por causa de um tempo cinzento e chuvoso, ela se apresenta "agasalhada" por um casaco com capuz; "Milliquet não lhe viu nem mesmo o rosto", insiste-se. Na seqüência, o texto multiplica as encenações de condições perceptivas difíceis; no início do capítulo IV, por exemplo, quando Juliette começou a trabalhar no café de seu tio, todos tentam vê-la:

[...] mas havia uns e outros que, por causa da condição sexual, da idade, ou até da falta de dinheiro, eram obrigados a ficar de fora; e todos olhavam pelos ladrilhos perfurados, pelas cortinas de guipura falsa, tentando ver se ela estava lá.

Viam apenas que o bar estava envolvido por uma fumaça espessa [...].**

"(: 35, grifos nossos.)

Estamos quase diante de uma redefinição da penumbra de tipo fantástico que torna real opaco. Aliás, a tarefa não é menos difícil para os clientes do interior do café, mas, desta vez, é o comportamento da heroína que está em questão: "Ela abaixava a cabeça sob seu lenço rendado. Era preciso inclinarse por sobre a mesa para ver seu rosto [...]”**.

Mais à frente, como abertura de uma das maiores cenas do romance, em que Juliette, sozinha em um barco, aparece como princípio unificador do mundo, não há mais nenhuma opacidade, e sim uma claridade intensa que perturba a visão de uma personagem observando o que está acontecendo; bem, isso não tem conseqüências para o alcance interpretativo do texto, pois é justamente por esse ponto de vista e pelo viés de uma forma de monólogo interior do observador que é mostrado o papel metafísico aparentemente desempenhado por Juliette:

Maurice move os olhos procurando a jangada, se lhe baralhou a vista querendo fixá-la em cima. Durante um bom tempo, nada distinguiu à sua frente senão círculos grená, vermelhos, róseos, círculos que, a partir do seu olhar, se vão alargando até preencherem completamente os dois orifícios de suas órbitas. Até ela, quando reapareceu, no meio de um dos círculos amarelos, não passou, 
"(:122e 124.5, grifos nossos.)

"(:255 e 256, grifos nossos.) inicialmente, de uma mancha do mesmo amarelo, como se a visão dele ainda o enganasse, e a criasse falsamente. [...]

Ele, do alto, ainda está olhando. [...] havia uma espécie de entendimento, uma troca contínua entre uma coisa e outra, e entre todas as coisas que existem. E em torno dela e por conta dela, lá no alto, ele pensa e fala consigo.*

Enfim, o desaparecimento súbito da moça, em companhia do acordeonista corcunda, dá-se em um caos meteorológico, em que os flashes dos relâmpagos são a única fonte luminosa que permite seguir, por intermitência, os acontecimentos:

A luz elétrica se apagara de uma vez por todas. Aqui, estávamos ao vento, sob os relâmpagos, e um trovão, que bramia repetidamente. Por instantes, e com longas pausas, chegavam, quando muito, uma ou duas notas, um acorde. O corcunda não foi mais visto; Juliette não foi mais vista. A noite cai sobre a cabeça e em volta dos ombros como o pano preto dos fotógrafos; depois ela aparece, se ilumina; subiu em uma mesa. Pode-se vê-la, não se pode mais. [...]

Noite - não, porque ela está lá, ela esteve lá novamente; ela mantém levantados os dois braços, a rosa lhe cai da orelha. [...] Depois se escutam umas notinhas baixas que parecem afastar-se, voltar, para se afastarem de novo; mas, o corcunda, onde estará? Não se pode mais vê-lo, tampouco o instrumento, nem de onde vem o som, porque ele trocou de lugar - mas, uma outra vez, ela foi trazida ao ar. Nele, o relâmpago a pinta; ela ainda ergue os braços; em seguida, está sem braços, sem corpo; imediatamente, ela não está mais; então, um último trovão fez, por um momento, que tudo deixasse de estar; ela também deixou de estar, e, quando um novo relâmpago clareou, ela não esteve mais ali..."*

Note-se que, mais uma vez, a cena é construída em torno de um núcleo perceptivo - os poucos protagonistas ainda presentes, que constituem, antes de qualquer coisa, o ponto de escuta em torno do qual "gira” o som do acordeão -, e que ela mescla uma voz narrativa a uma outra que toma a forma de um monólogo interior (a forma do enunciado "mas o corcunda, onde estará?” é a marca mais evidente disso). A adjunção de um componente diegético (do tipo motivo tópico) reforça a estruturação textual que privilegia a restrição - tanto perceptiva quanto cognitiva e aumenta o sentimento de indeterminação interpretativa que tentamos destacar no romance.

\subsection{Memória comum versus alucinação coletiva}

Talvez pareça, então, que Ramuz tenha remodelado elementos da tópica fantástica. Nenhum nevoeiro, nenhuma obscu- 
ridade insondável, nenhuma fadiga nervosa, nem quaisquer ausências provocadas pelo uso de álcool ou de substâncias psicotrópicas, fenômenos que conduzem a um "desregramento dos sentidos”; mas há sim um manto incolor e disforme, uma fumaça espessa de cachimbos e charutos, um sol ofuscante, relâmpagos intermitentes, que, cada um a seu modo, põem obstáculos à percepção que as outras personagens têm de Juliette. O escritor, contudo, não se limitou a isso e fez com que o sentimento de indeterminação fosse convocado explicitamente ao longo do texto. São essas as últimas "instruções" de leitura que gostaríamos de engendrar, e que deveriam banir qualquer possibilidade de uma interpretação unívoca de La beauté sur la terre.

Dissemos que a instância narradora primeira figurava como um narrador testemunha coletiva, e que ele mesmo confiava a condução da narrativa a outros narradores, cujas intervenções figuravam, cada uma, como depoimentos. Essa estrutura narrativa cria, parcialmente, um efeito de leitura específico: parece que assistíamos a uma verdadeira reconstituição do que era dado como fatos ancorados em uma memória comum. Com efeito, essa memória é, às vezes, convocada no decorrer da narrativa; no capítulo III, Rouge, quando "toma a palavra" à instância narradora primeira, refere-se, por duas vezes, a uma lembrança compartilhada com seu destinatário: "E depois, lembre-se, quando ela chegou [...]. É só você se lembrar da entrada..."*.

No último capítulo (XIII), é uma instância não definida que aciona a existência de uma lembrança: "Lembram que, naquele momento, ela [Juliette] estava assentada sobre a mesa, e, perto dela, Rouge, em um banco"*

Os apelos a uma memória coletiva estão localizados em pontos-chave da narrativa, justamente antes da primeira e da última aparição pública de Juliette. Eles funcionam, assim, como "limites" que poderiam arrimar o restante do texto no campo do factual. Imediatamente, contudo, fazemlhes concorrência outras instruções textuais que, por outro lado, tendem a conduzir a narrativa para o campo ficcional: trata-se de intervenções em forma de comentários, cuja proveniência é a instância narrativa primeira ou os próprios narradores intradiegéticos. Desse modo, a tensão entre testemunho verídico e fabulação é estabelecida já na primeira 
(: 31, grifos nossos.)

(: 58, 183, 251, 255, grifos nossos.) intervenção de Rouge como narrador, anteriormente evocado, na qual ele descreve a música tocada pelo acordeonista corcunda:

E um instrumento como aquele se escuta até a um quilômetro. A prova é que ela o escutou de seu quarto, e que, embora deitada, o tenha escutado de sua cama (ele estava inventando). Foi a música que a fez levantar-se [...] Sem a música, eu lhes asseguro, ela não se teria movido; aliás, foi ela quem me disse isso."

Entre seus dois "limites memoriais", o texto não cessa, enfim, de apresentar um questionamento sobre a exatidão da lembrança, marcando suas lacunas, e fazendo-o descambar para a fantasia ou a ficção:

Ela olhava as pedras redondas e lisas por conta de suas belas cores. [...]. Continuamos a história, de modo que aqui já brilhavam para os seus olhos, para lhe agradar, toda sorte de belas pedras pintadas […].

Talvez também ela se tenha acabado, porque também ela se tinha inventado (ou talvez a tivessem inventado).

Contaram depois que nesse momento o corcunda havia tirado seu chapéu e colocado ao seu lado [...].

Ora, será mesmo ela que ainda está aqui, por um pequeno instante?*

É impossível não entender alguns desses comentários como sendo extremamente autotélicos: por eles, La beauté sur la terre se designa "ficção". Disso só pode resultar que eles também devem ser entendidos como elementos que relatam a dúvida instalada pontual ou duravelmente nos protagonistas - e que contamina, pouco a pouco, o leitor do romance.

É nesse ponto que gostaríamos de encerrar nosso estudo: reconsiderando a poética de La beauté sur la terre como pertencente, essencialmente, ao universo fantástico.

Uma narração não-onisciente, alguns dispositivos visando restringir a informação (perceptiva ou cognitiva), uma figura central que se apreende muito dificilmente: tudo isso não basta para que se designe um texto como fantástico. Um sem-número de narradores não oniscientes relatam histórias em que nada está sujeito a dúvidas; e lembremonos de que o incipit de Madame Bovary apresenta um narrador testemunha coletiva semelhante ao narrador primeiro de La beauté sur la terre. Do mesmo modo, a restrição da 
informação é uma estratégia constitutiva de vários gêneros romanescos, desde que se trate de controlar o suspense, a surpresa, os saltos... Sobre a fraca representação do temperamento de Juliette, dissemos que ela podia ser necessária ao projeto de escrita de Ramuz, na tentativa de representar um absoluto.

Contudo a aproximação do gênero fantástico não parece incongruente. Se nos ativermos ao modo como Todorov (1970) define o fantástico, veremos que esse gênero é constituído, antes de qualquer coisa, por uma indeterminação interpretativa final. Insistimos nesse ponto: muitas vezes, associa-se o fantástico a aspectos do conteúdo de uma obra - duplos, fantasmas, demônios etc. Mas não é aí que se situa o fundamento do gênero; os monstros e os fenômenos sobrenaturais abundam nos contos maravilhosos... e, com efeito, sua existência não é posta em dúvida, o que faz que essa modalidade de textos não entre na categoria "fantástico".

Qualquer fenômeno estrutural que torne possível uma indeterminação interpretativa pode servir ao fantástico. É o caso, por exemplo, de um dispositivo narrativo que não se constrói com onisciência, mas, ao contrário, com limites cognitivos. É também esse o efeito que produzem alguns regimes de focalização, ocularização e auricularização, que permitem uma gestão da informação veiculada pelo texto próxima da retenção. Mas essa gestão específica é fundamental por permitir que a hesitação da ou das personagens seja redobrada pela hesitação do leitor, uma das condições do fantástico:

É [a personagem] que, no decorrer da trama, deverá escolher entre duas interpretações. Mas se o leitor fosse prevenido a respeito da "verdade", se soubesse por qual sentido se decidir, a situação seria muito diferente. O fantástico, portanto, implica uma integração do leitor com o mundo das personagens; ele se define pela percepção ambígua que tem o próprio leitor dos acontecimentos relatados."

O trabalho que tentamos realizar e os elementos que extraímos do texto para apresentar ao nosso próprio leitor deveriam levá-lo a ler ou reler La beauté sur la terre - e quem sabe muitos outros romances de Ramuz - com um pouco mais de prudência do que a crítica, a qual, até o presente, não hesitou em se decidir pelo sobrenatural. Parece-nos que, ao fim do romance, o leitor deveria dizer, parafraseando a fórmula
"(Todorov, Tzvetan. Introduc(t)érature fantastique. Paris: Seuil, 1970: 35-6.) 
(modelo do espírito fantástico, segundo Todorov) do herói de Manuscrito encontrado em Saragossa: "Eu quase chego a crer que Afrodite escolheu encarnar-se, mais uma vez, com as feições da jovem Juliette”.

Tradução: Matosalém Vilarino Pereira 


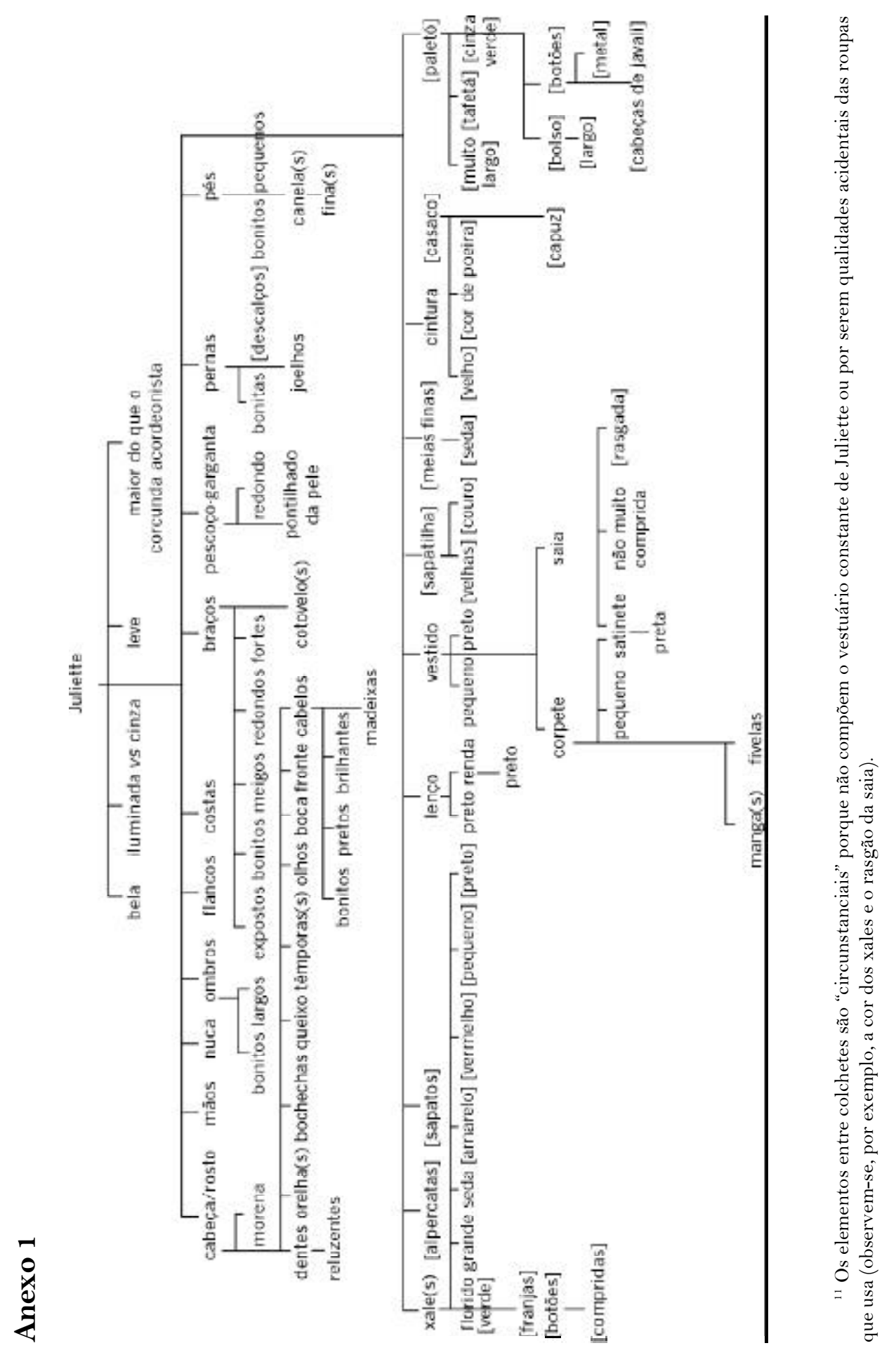



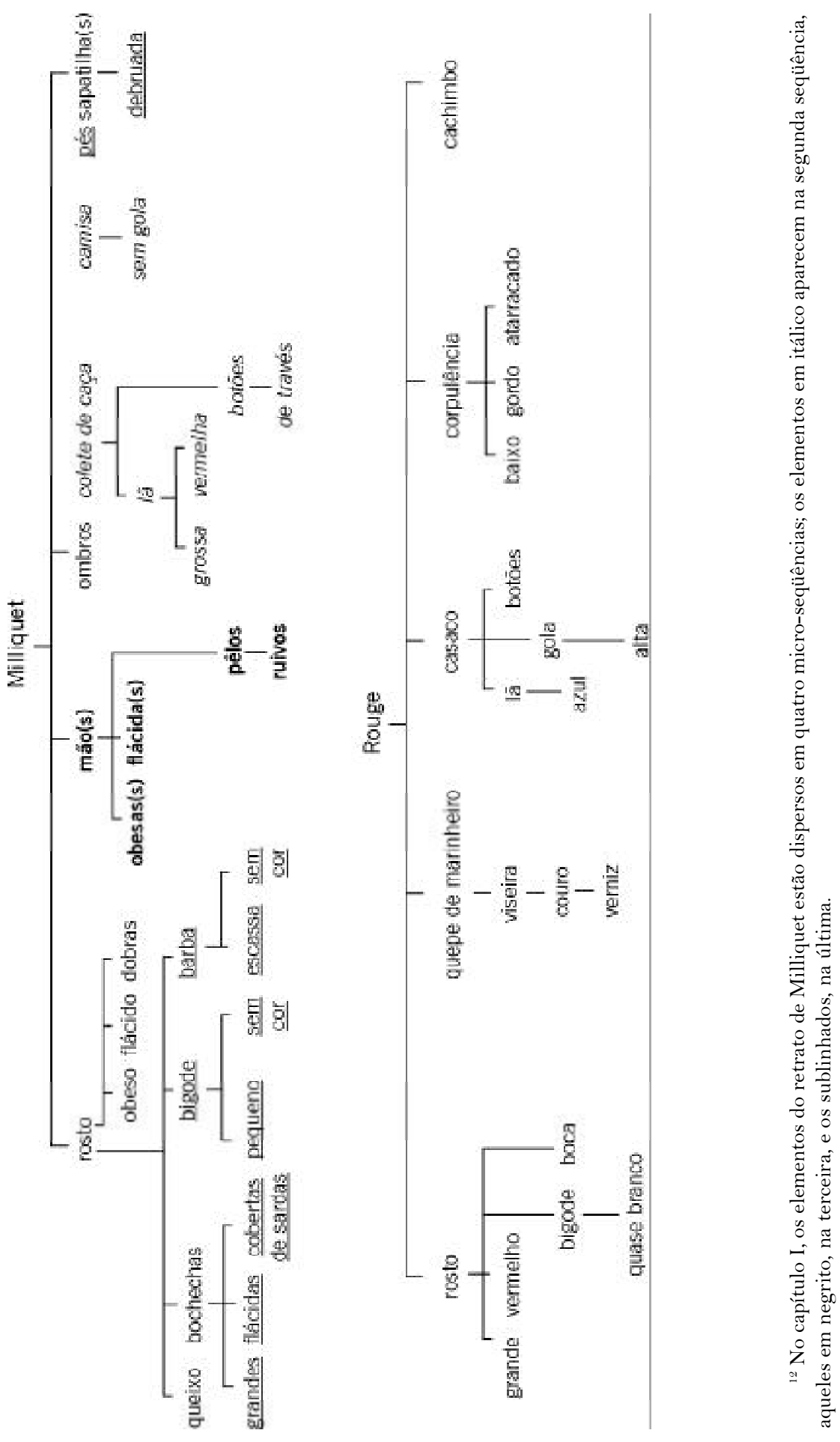
Vincent Verselle

Doutorando na Universidade de Lausanne (Suíça). Desde maio de 2000, ocupa o posto de colaborador científico no Centro de Pesquisa em Letras Romandas, participando da equipe que prepara duas edições comentadas das obras de C.-F. Ramuz (nas edições Gallimard e na Slatkine). Nesta função, co-redigiu a introdução de La beauté sur la terre (um dos 22 romances a sair pela Gallimard na Bibliothèque de la Pléiade).

\section{Resumo}

La beauté sur la terre (1927), de C.-F. Ramuz, é um romance sobre a alteridade, devido ao fato de sua personagem central, Juliette, ser uma jovem órfã cubana que repentinamente se vê em um povoado às margens do lago Léman. Alteridade cultural, mas sobretudo, como o romance parece pouco a pouco dizer, alteridade de natureza: Juliette aparece para vários personagens (e talvez para o leitor) como a encarnação do Belo - uma nova Afrodite. Este artigo se propõe, assim, a estudar por quais inclinações textuais tal aura "divina” é conferida a Juliette. Trata-se, antes de tudo, de observar o sistema de retratos do romance e as características próprias à descrição da personagem central; essas são relacionadas, em seguida, à estrutura narrativa particular do texto, sendo percebidas como efeitos dele; por fim, tal estrutura narrativa é ela mesma considerada, sob um ângulo genérico, como uma das dimensões constitutivas de uma poética do fantástico concebida por C.-F. Ramuz.

Palavras-chave
Ramuz
poética
retrato
ocularização
gênero
fantástico
alteridade
Key words
Ramuz
poetics
portrait
ocularization
focalization
genre
the fantastic
otherness
Mots-clés
Ramuz
poétique
portrait
ocularisation
focalisation
genre
fantastique
altérité

\section{Abstract}

C.-F. Ramuz's La beauté sur la terre (1927) is a novel of otherness because of its main character, Juliette, a young Cuban orphan who suddenly finds herself in a village on the shores of the Léman lake. Cultural otherness, but above all, as the novel little by little seems to express, otherness of nature: Juliette appears to many characters (and perhaps to the reader) as the embodiment of Beauty - a new Aphrodite. This paper sets itself the task of studying the textual devices by means of which such a "divine" aura is conferred on Juliette. In

\section{Résumé}

La beauté sur la terre (1927), de C. F. Ramuz, est un roman de l'altérité, par le fait de son personnage central, Juliette, être une jeune $\mathrm{Cu}$ baine orpheline qui se retrouve soudain dans un village du bord de lac Léman. Altérité culturelle, mais surtout, comme le roman semble le dire petit à petit, altérité de nature: Juliette apparaît à plusieurs personnages (et peutêtre au lecteur) comme étant l'incarnation de la Beauté - c'est une nouvelle Aphrodite. Cet article se propose alors d'étudier par quels biais textuels une telle aura "divine” se retrouve conférée à Ju- 
Recebido em $31 / 10 / 2003$

Aprovado em Apro3/2004 the first place, the system of portraits in the novel is discussed, together with the traits belonging to the main character's description; the former are then related to the text's particular narrative structure, being perceived as its effects; finally, this narrative structure is itself considered in its generic scope as one of the constitutive dimensions of a poetics of the fantastic, as C.-F. Ramuz was able to devise. liette. Il s'agit tout d'abord d'observer le système des portraits du roman et les caractéristiques propres à la description du personnage central; celles-là sont rattachées dans un deuxième temps à la structure narrative particulière du texte, en étant perçues comme ses effets; enfin, cette structure narrative est elle-même considérée, sous un angle générique, comme une des dimensions constitutives d'une poétique du fantastique telle que C.-F. Ramuz a pu la concevoir. 